\title{
Література
}

1987. - 237 c

2. Нартов К. М. Взаимосвязи отечественной и зарубежной литератур в школьном курсе : книга для учителя / К. М. Нартов. - М. : Просвещение, 1986. - 191 с.

3. Нечуй-Левицький I. Хмари. Над чорним морем: повісті / I. Нечуй-Левицький. К. : Дніпро, 2004. - 552 с.

4. Миропольська Н. Є. Формування художньої культури учнів загальноосвітньої школи засобами мистецтва слова : дис... доктора пед. наук : 13.00.01 / Миропольська Наталія Свгенівна. - К., 2003. - 394 с.

5. Шевченко Г. П. Эстетическое воспитание в школе : [учебно-метод. пособие] / Г. П. Шевченко. - К. : Рад. школа, 1985. - 144 с.

Стаття надійшла до редакції 30.04.2012 p.

УДК 378:[37.016:331]

M. А. Пригодій, кандидат пед. наук, доцент, Чернігівський національний педагогічний університет імені Т. Г. Шевченка

\section{РОЗРОБЛЕННЯ КРИТЕРЇ̈В ТА РІВНІВ ОЦІНЮВАННЯ ГОТОВНОСТІ МАЙБУТНІХ УЧИТЕЛІВ ДО ПРОФІЛЬНОГО НАВЧАННЯ УЧНІВ}

Пригодій М. А. Розроблення критеріїв та рівні оцінювання готовності майбутніх учителів до профільного навчання учнів.

У статті подано результати теоретичного узагальнення з проблеми обтрунтування критеріїв та рівнів оцінювання готовності майбутніх учителів до профільного навчання учнів.

Ключові слова: критерій, показник, готовність до профільного навчання, вчитель технологій.

Пригодий Н. А. Разработка критериев и уровней оценивания готовности будущих учителей к профильного обучения учашихся.

В статье раскрываются результаты теоретического обобщения по проблеме обоснования критериев и уровней оценки готовности будущих учителей к профильному обучению учащихся.

Ключевые слова: критерий, показатель готовности к профильному обучению, учитель технологий.

Prigodiy M. Design criteria for evaluation and levels of readiness to teachers training student profile.

The article describes the results of theoretical generalizations on the issue of justification criteria and levels of readiness assessment of future teachers for Special Education students.

Key words: criterion, measure readiness for school education, a teacher of technology.

Актуальність теми. Модернізація всіх галузей вітчизняної економіки характеризується зростанням інтенсивності інформаційних процесів, потребою сучасного суспільства в гнучких, адаптивних системах освіти. Як наслідок, виникає необхідність прискорення процесів становлення нової освітньої політики, формування нових цілей змісту освіти, перехід від парадигми навчання до парадигми самонавчання. У зв'язку з цим профільне навчання $є$ одним 3 пріоритетних напрямків оновлення сучасної освіти, досягнення нею нової якості, здійснюється переорієнтація на створення нових знань, нового соціально значимого досвіду. Розв'язання цих завдань вимагає посилення професійної підготовки майбутнього вчителя для роботи 
у профільній школі. Це актуалізує проблему пошуку умов формування та методики оцінювання готовності майбутнього вчителя технологій до профільного навчання учнів загальноосвітніх навчальних закладів.

Проблема готовності людини до певного виду діяльності $\epsilon$ багатогранною, що пов'язано 3 необхідністю врахування не лише об’єктивних, а й суб'єктивних аспектів діяльності людини.

Як об'єкт оцінювання, цей вид професійної діяльності майбутніх учителів технологій дуже складний у зв'язку зі значною часткою його новизни i не розробленістю критеріїв і норм, що дозволяють визначити готовність випускників педагогічних вишів до профільного навчання учнів.

Мета статті - обгрунтування критеріїв та рівнів оцінювання готовності майбутніх учителів до профільного навчання учнів.

Аналіз попередніх досліджень. Аналіз психолого-педагогічних досліджень дозволив встановити, що готовність до педагогічної діяльності розглядається як озброєння знаннями, вміннями, навичками, як бажання індивіда та його можливість реалізувати наявну програму дій в соціумі (М. Д’яченко, Л. Кандибович, В. Сєріков); історично-традиційний підхід до розуміння готовності через змістовий аспект, тобто через знання, уміння та навички (Б. Ананьєв, Б. Ломов, К. Платонов).У інших дослідженнях дане поняття розкривається як внутрішня властивість, певна якість особистості (А. Асмолов, Е. Зеєр); структурними компонентами готовності студентів педагогічного вишу, як результат їх професійної підготовки, визначені потреби, здібності та рішучість (Т. Кружиліна, Л. Абдулліна). Також готовність розглядають як певну інтегративну якість, що охоплює мотиваційний, змістовий та діяльнісний компоненти (О. Госсе, В. Сластенін, О. Щербаков); існує й інший підхід до трьохкомпонентного змісту готовності, що включає психологічну, теоретичну та практичну готовність (Г. Балл, П. Перепелиця, В. Рибалка). Окремі дослідники розширюють коло компонентів готовності, відповідно визначаючи такі з них, як мотиваційний, когнітивний, операційний, емоційно-вольовий та інформаційний компоненти (К. Муратова та I. Федоров), або когнітивний, діяльнісно-технологічний, емоційно-ціннісний, інтеграційний компоненти (Т. Гуменникова). Економічний словник взагалі розширює кількість компонентів готовності до шести: мотиваційний, змістово-діяльнісний, інтелектуальний, комунікаційно-методичний (технологічний), результативний и прогностичний.

Виклад матеріалу. Аналіз підходів визначення компонентів готовності до професійної діяльності майбутніх фахівців дозволяє окреслити чітку структуру, що складається з умовних трьох сфер:

1 сфера - позитивне ставлення фахівця (чи майбутнього фахівця) до сфери професійних інтересів.

2 сфера - стан теоретично-практичної підготовки фахівця до професійної діяльності.

3 сфера - готовність до самовдосконалення та саморозвитку в межах професійної діяльності. 
Отже, готовність майбутніх учителів технологій до профільного навчання учнів загальноосвітніх навчальних закладів будемо розглядати 3 урахуванням таких структурних компонентів:

Мотиваційний компонент - позитивне ставлення до професії вчителя, інтерес до особливостей професійної діяльності вчителя технологій, розуміння необхідності здійснення профілізації навчання в загальноосвітніх навчальних закладах, потреба в неперервному саморозвитку та самоосвіті для успішної педагогічної діяльності.

Діяльнісно-орієнтаційний компонент - знання та уявлення про особливості та умови діяльності вчителя технологій з учнями профільних класів, знання вимог до вчителя профільного навчання учнів загальноосвітніх навчальних закладів, уміння здійснювати планування та володіння методикою допрофільного та профільного навчання учнів загальноосвітніх навчальних закладів, необхідними знаннями та уміннями з профорієнтаційної роботи.

Рефлексивний компонент - здатність до самоконтролю майбутнього вчителя технологій, уміння керувати власною діяльністю, самооцінка вчителем технологій власного рівня професійної підготовки та відповідності обраних навчально-виховних заходів завданням, що виникають у процесі профільного навчання учнів загальноосвітніх навчальних закладів.

Задля оцінювання готовності майбутніх учителів технологій до профільного навчання учнів необхідно визначити критерії та показники на основі розробленої трьохкомпонентної структури. Цей критеріальний апарат необхідний для визначення інтегративних та диференційних показників готовності.

Задля визначення показників та критеріїв оцінювання рівня готовності майбутніх учителів технологій до профільного навчання учнів, необхідно встановити чітке розмежування даних понять. На основі аналізу літератури $[2 ; 3 ; 5]$ встановлено, що критерій - це ознака, на грунті якої здійснюється оцінка, визначення або класифікація чого-небудь; мірило судження, оцінки.

Отже, критерій готовності майбутнього вчителя технологій до профільного навчання учнів загальноосвітніх навчальних закладів, це ознака, за допомогою якої здійснюється визначення розвитку якостей особистості та сформованості знань та умінь з проблем профілізації навчання.

К. Муратова та I. Федоров указують на ознаки, яким повинні задовольняти критерії - об'єктивність, однозначність, адекватність, валідність, нейтральність у відношенні до явищ і процесів, що аналізуються. Під час проведення психолого-педагогічних досліджень рекомендується використовувати групи критеріїв - результативних і процесуальних, об'єктивних і суб'єктивних, якісних і кількісних, внутрішніх і зовнішніх, інтегральних та диференціальних, експертних і саморефлексівних [4].

Загальні вимоги, що висуваються до критеріїв оцінювання готовності майбутніх учителів до професійної діяльності, такі: критерії повинні описувати лише основні процеси чи елементи (не використовувати критерії, що відображають другорядні закономірності); критерії слід підбирати такі, щоб вони утворювали систему, що розкриває усі елементи явища, що 
аналізується; критерії повинні описувати лише динамічні процеси (динаміка дозволяє здійснити оцінювання ефективності різноманітних впливів на об’єкт чи процес); критерії повинні бути дискретними, тобто такими, що можуть бути розкриті через певні показники, за допомогою яких можна визначити ступінь вияву певного критерію.

Критерії повинні розкриватися через систему показників, визначення та узагальнення яких дозволяє виявити рівень готовності майбутніх учителів технологій до профільного навчання учнів загальноосвітніх навчальних закладів.

Відповідно до словника С. Ожегова, показник - це те, за чим можна судити про розвиток та перебіг чого-небудь [5, с. 474]. Отже, показник - це кількісна чи якісна характеристика сформованості критерію готовності майбутніх учителів технологій до профільного навчання учнів, що може бутипевним чином виміряна.

На основі проведеного дослідження, узагальнення накопиченого досвіду 3 організації профільного навчання у загальноосвітніх навчальних закладах було визначено компоненти, критерії та показники оцінювання готовності майбутніх учителів технологій до профільного навчання учнів (табл. 1).

Таблиияя 1

Елементи оцінювання готовності майбутніх учителів технологій до профільного навчання учнів загальноосвітніх навчальних закладів

\begin{tabular}{|c|c|c|}
\hline $\begin{array}{l}\text { Компонент } \\
\text { готовності }\end{array}$ & Критерій & Показник \\
\hline \multirow[t]{3}{*}{$\begin{array}{l}\text { Мотиваційний } \\
\text { компонент }\end{array}$} & $\begin{array}{l}\text { Ступінь позитивного ставлення до } \\
\text { професії вчителя технологій }\end{array}$ & $\begin{array}{l}\text { Iнтерес до майбутньої педагогічної } \\
\text { діяльності }\end{array}$ \\
\hline & $\begin{array}{l}\text { Ступінь розуміння необхідності } \\
\text { здійснення профілізації навчання в } \\
\text { загальноосвітніх навчальних закладах }\end{array}$ & $\begin{array}{l}\text { Усвідомлення ролі профільного } \\
\text { навчання учнів загальноосвітніх } \\
\text { навчальних закладів на сучасному } \\
\text { етапі розвитку суспільства }\end{array}$ \\
\hline & $\begin{array}{l}\text { Ступінь актуалізації потреби у } \\
\text { неперервному саморозвитку та самоосвіті } \\
\text { для успішної педагогічної діяльності }\end{array}$ & $\begin{array}{l}\text { Зацікавленість у збільшенні знань } 3 \\
\text { профільного навчання учнів } \\
\text { загальноосвітніх навчальних закладів }\end{array}$ \\
\hline \multirow[t]{3}{*}{\begin{tabular}{|l} 
Діяльнісно- \\
орієнтаційний \\
компонент
\end{tabular}} & $\begin{array}{l}\text { Обізнаність про особливості, умови } \\
\text { діяльності та вимоги до вчителя } \\
\text { профільного навчання учнів } \\
\text { загальноосвітніх навчальних закладів }\end{array}$ & $\begin{array}{l}\text { Знання особливостей, умов діяльності } \\
\text { та вимог до вчителя профільного } \\
\text { навчання учнів загальноосвітніх } \\
\text { навчальних закладів } \\
\end{array}$ \\
\hline & $\begin{array}{l}\text { Ступінь володіння методикою } \\
\text { допрофільного та профільного } \\
\text { навчання учнів загальноосвітніх } \\
\text { навчальних закладів }\end{array}$ & $\begin{array}{l}\text { Уміння планувати та проводити уроки } \\
\text { на етапі допрофільного та } \\
\text { профільного навчання учнів загально- } \\
\text { освітніх навчальних закладів }\end{array}$ \\
\hline & $\begin{array}{l}\text { Ступінь володіння основами організації } \\
\text { профорієнтаційної роботи з учнями } \\
\text { загальноосвітніх навчальних закладів }\end{array}$ & $\begin{array}{l}\text { Уміння організовувати профорієнтаційну } \\
\text { роботу з учнями на етапі допрофільної та } \\
\text { профільної підготовки }\end{array}$ \\
\hline \multirow[t]{2}{*}{$\begin{array}{l}\text { Рефлексивний } \\
\text { компонент }\end{array}$} & $\begin{array}{l}\text { Здатність до самоорганізації та } \\
\text { контролю професійної діяльності } \\
\text { майбутнім учителем технологій }\end{array}$ & $\begin{array}{l}\text { Уміння керувати власною } \\
\text { професійною діяльністю }\end{array}$ \\
\hline & $\begin{array}{l}\text { Здатність до самооцінки майбутнім } \\
\text { учителем технологій власного рівня } \\
\text { професійної підготовки }\end{array}$ & $\begin{array}{l}\text { Уміння оцінювати відповідність } \\
\text { обраних навчально-виховних заходів } \\
\text { завданням, що виникають у процесі } \\
\text { профільного навчання учнів } \\
\text { загальноосвітніх навчальних закладів } \\
\end{array}$ \\
\hline
\end{tabular}


Задля визначення шкали оцінювання рівнів готовності майбутніх учителів технологій до профільного навчання учнів загальноосвітніх навчальних закладів, будемо використовувати за основу стобальну шкалу оцінювання знань студентів у кредитно-модульній системі [1]. Такий підхід дозволяє розробити чотирирівневу шкалу, що може бути використаною для аналізу кожного критерію готовності та $є$ адаптованою для використання у процесі підготовки майбутніх учителів технологій (табл. 2).

Табличя 2

Рівні готовності майбутніх учителів технологій до профільного навчання учнів загальноосвітніх навчальних закладів

\begin{tabular}{|l|l|l|}
\hline \multicolumn{1}{|c|}{ Рівень } & \multicolumn{1}{|c|}{ Діапазон показника, $\%$} & \multicolumn{1}{|c|}{ За шкалою КМСОНП та ВНЗ } \\
\hline Високий & від 90,00 до 100,00 & $\mathrm{~A}(90-100)$ \\
\hline \multirow{2}{*}{ Середній } & \multirow{2}{*}{ від 75,00 до 89,99} & $\mathrm{~B}(82-89)$ \\
\cline { 3 - 4 } & & $\mathrm{C}(75-81)$ \\
\hline \multirow{2}{*}{ Достатній } & \multirow{2}{*}{ від 60,00 до 74,99 } & $\mathrm{D}(67-74)$ \\
\cline { 3 - 4 } & & $\mathrm{E}(60-66)$ \\
\hline \multirow{2}{*}{ Низький } & \multirow{2}{*}{ від 0,00 до 59,99 } & $\mathrm{FX}(1-36-59)$ \\
\hline
\end{tabular}

Висновок. Готовність майбутніх учителів технологій до профільного навчання учнів загальноосвітніх навчальних закладів раціонально оцінювати у межах таких структурних компонентів: мотиваційний, діяльнісноорієнтаційний, рефлексивний. Для чого необхідно використовувати шкалу оцінювання якості навчальних досягнень студентів вищих навчальних закладів ECTS, а саме (A - високий, B,C - середній, D,E - достатній, F низький). Такий підхід дозволяє отримати чотирирівневий розподіл даних відповідно до кожного показника, що характеризує критерії готовності.

Перспективи подалыших досліджень полягають у визначенні рівня готовності майбутнього вчителя технологій до профільного навчання учнів загальноосвітніх навчальних закладів, для чого необхідно провести вимірювання кожного з визначених показників та отримані результати об'єднати у єдиний коефіцієнт, на основі якого можна здійснювати порівняльний аналіз.

\section{Література}

1. Вища освіта України і Болонський процес: [навч.посіб.] / М. Ф. Степко, Я. Я. Болюбаш， В.Д.Шинкарук， В.В.Грубінко, . І. Бабін ; за ред.В.Г.Кременя. Тернопіль: Навчальна книга - Богдан, 2004. - 384 с.

2. Етимологічний словник української мови: У 7 т. / [гол.ред. О. Мельничук]. - К. : Наук. думка, 1982-2003. - Т. 3. - 552 с.

3. Значение слова «Критерий» в Большой Советской Энциклопедии [Електронний pecypc] / Большая Советская Энциклопедия [назва з титул. екрану]. - Режим доступу до енциклопедіï: http://bse.sci-lib.com/article066422.html.

4. Муратова Е. И. Проектирование и реализация образовательных программ подготовки специалистов инновационного типа / Е. И. Муратова, И. В. Федоров // Проблеми інженерно-педагогічної освіти : [зб. наук. праць]. - 2009. - № 22-23. - С. 16-29.

5. Ожегов С. И. Словарь русского языка: ок. 57000 слов / С. И. Ожегов; под ред. Н. Ю. Шведовой. - М. : Рус. яз., 1986. - 797 с.

Стаття надійшла до редакції 18.05.2012 p. 